ELORE (ISSN 1456-3010), vol. $13-1 / 2006$.

Julkaisija: Suomen Kansantietouden Tutkijain Seura ry. Taitto: Jukka Talve.

[http://cc.joensuu.fi/ loristi/1_06/kak1_06.pdf]

\title{
Ajankohtaista:
}

KURISSA JA HERRAN NUHTEESSA

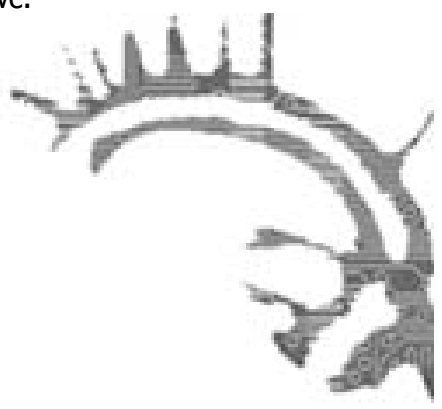

Lectio praecursoria Turun yliopistossa 17.12.2005.

Tarja Kakko

Emeritusprofessori Heikki Kirkinen toteaa kirjassaan Historian rakenteet ja voimat, että yhteiskuntaa pitävät koossa toiminta- ja koherenssirakenteet, joiden tarkastelu edellyttää ihmiskunnan kehityksen tarkastelua. Toimintarakenteet, kuten valtio, heimo tai klaani, ovat organisaatiomuotoja, joiden puitteissa ja avulla ihmiset toimivat. Koherenssirakenteet sitä vastoin ovat yhteisöjen koossa pysymistä ja kehitystä tukevia rakennekokonaisuuksia, jotka liittyvät yhteisöjen elämäntapaan ja identiteettiin. (Kirkinen 1987, 128-134, 141.)

Rakenteiden ohella, ja usein niihin liittyen, historian kulkuun vaikuttavat myös erilaiset biologiset ja psyykkiset voimat. Niiden rooli voidaan rinnastaa luonnonlakeihin: biologiset ja psyykkiset voimat ovat mukana kaikessa inhimillisessä toiminnassa riippumatta siitä, toimiiko ihminen yksilönä, ryhmän tai yhteisön jäsenenä. Heikki Kirkinen toteaa, että historiallisten tapahtumien ja ilmiöiden selittämisessä on tullut tavaksi pyrkiä analysoimaan menneisyyden ihmisen toiminnan motiiveja. Historiallisessa selittämisessä huomio kohdistuu sen henkisen todellisuuden ymmärtämiseen ja selittämiseen, jonka turvin ihminen etenee ja tekee elämässään ratkaisuja. Motiivianalyysi on yksi mahdollinen apuväline, jonka avulla voidaan osoittaa ne tekijät, jotka ovat johtaneet toisinaan epäonnistumisiin ja virheratkaisuihin, toisinaan taas onnistumisiin ja suunnitelmien toteutumiseen. (Kirkinen 1987, 24-25, 41, 143-149.)

Historian tarkastelu osoittaa, että erilaiset rakenteet muodostavat usein yhteisön toimintaa, elämäntapaa ja kehitystä tukevia pitkäaikaisia puitteita, mutta ne voivat myös muuttua aikojen kuluessa. Yhteiskuntarakenteiden muutokseen, yhteiskunnalliseen murrokseen voi joskus liittyä jopa fanaattisia piirteitä. Näin tapahtuu varsinkin silloin, jos staattisen ja suljetun yhteiskunnan kansalaiset joutuvat yhteiskunnan henkisen ilmapiirin vapauduttua kohtaamaan vieraiden kansojen tai kulttuurien edustajia, jotka koetaan uhkana tai epäilyttävinä. Oma kulttuuri, uskon- 


\section{TARJA KAKKO}

to tai aate pitää yllä turvallisuuden tunnetta, jota vieras järkyttää. Fanaattisuus on käyttäytymismalli, joka on lähes kaikkien kansojen, uskontojen ja ideologioiden osatekijä. (Kirkinen 1987, 14, 146-147.)

Aate on aatteen synnyttäjän persoonallisuuden jälki, joka ei ole suoraan vaikuttavaa energiaa vaan vaikuttavat voimat ovat elävissä ihmisissä. Aatejärjestelmä on laatijansa sekä sen itselleen omaksuneiden mielessä tietoa yhteiskunnallisesta todellisuudesta ja voi siinä ominaisuudessa vaikuttaa persoonallisuuden sisäisenä voimana toiminnan suunnitteluun tai itse toimintaan. Ideologiaksi aatejärjestelmä muuttuu silloin, kun siihen sisältyy ideaaliksi omaksuttu maailmankatsomus, joka todellisuuden kuvauksena ja toiminnan motivaatiotaustana vaikuttaa yksilön tai yhteisön toiminnan tavoitteellisuuteen. Vaikka aatteiden syntymiseen vaikuttavat monet erilaiset tekijät, kuten taloudelliset rakenteet tai perinne, niitä ja niiden osuutta historiassa voidaan silti tarkastella myös itsenäisesti, ymmärtää ne voimana, josta kumpuavat esiin monet ihmismielen luovat henkiset kyvyt. (Kirkinen 1987, 149_ 153.)

Aatteet, kuten ideologiatkin, heijastavat yhteiskunnan tajuntaa ja tietoisuutta yhteiskunnallisina toimijoina. Aatteilla ja ideologioilla on huomattava vaikutus ihmisen toimintaan ja historialliseen kehitykseen. Kehityksellä tarkoitetaan yleensä muutoksia, joilla on yhteinen suunta: eteenpäin. Kehitys on edistystä ja siihen liittyy arvovaraus. Se on etenemistä alhaalta ylöspäin, huonommaksi arvioidusta kohti parempana pidettyyn. Kulttuurikehityksessä ihmisen innovaation tulokset kuitenkin kumuloituvat ja uusia ennalta arvaamattomia vaikutustekijöitä nousee esiin muuttaen historian kulkua. Kulttuurikehitys ei näin ollen aina ole askel eteenpäin vaan säännönmukainen tai konventioita rikkova muutosprosessi, joka voi joskus osoittautua jopa kohtalokkaaksi, jos siihen sisältyy virhearviointeja. (Kirkinen 1987, 149-153.)

1800-luvun lopun suomalaisessa yhteiskunnassa elettiin murrosaikaa. Asteittainen siirtyminen agraariyhteiskunnasta teolliseen yhteiskuntaan sai aikaan paitsi edistystä ja suuria yhteiskunnallisia muutoksia myös ongelmia. Teollistumisen ja lisääntyneen muuttoliikkeen seurauksena perhe- ja sukuyhteydet katkesivat, mistä syystä muun muassa lasten asema heikkeni. Lapset, jotka agraariyhteiskunnassa tuli hoidettua "siinä sivussa", vanhempien työn lomassa, elivät yllättäen tilanteessa, jossa koti oli tyhjä - siellä ei ollut enää ketään. Syynä saattoi olla perheiden muutto maalta kaupunkiin, äitien lisääntynyt ansiotyö tai ero isovanhemmista, jotka jäivät maalle hoitamaan koti- tai sukutilaa. Jokainen kasvattaja ymmärtää, mitä kyseinen muutos merkitsi: lapset etsivät seuraa ystäväpiiristä, jolloin lapsista muodostui nopeasti ryhmä, jota yksikään perhe ei halunnut tai voinut päästää asuntoonsa. Siitä seurasi, että lapset viihtyivät, varsinkin kaupungeissa, yhä useammin kadulla. Kaduista tuli lasten leikkipaikka, jossa ilkivalta ja huonot elämäntavat lisääntyivät. Äiti, isä ja isovanhemmat, jotka aikaisemmin olivat olleet lasten esikuvia ja moraalinvartijoita, eivät olleet enää pitämässä lapsista huolta eivätkä ohjaamassa heidän elämäänsä. Koherenssirakenne, konkreettinen sukupolvien välinen ketju, jonka tarkoitus Heikki Kirkisen mukaan on lujittaa yhteisön koossa pysymistä ja identiteettiä pitkäjänteisellä tavalla aikaperspektiivissä, katkesi. 
Yhteiskunnallisessa murroksessa, yhteiskuntarakenteiden murtuessa pohditaan paitsi kaikkea sitä, mitä entisessä olisi säilyttämisen arvoista, myös sitä, mistä tulisi luopua tulevaisuuden hyväksi. Kristillinen kasvatus, jota luterilaisen kasvatusideologian mukaan oli opetettu ja toteutettu Suomessa jo 1600-luvulta lähtien, oli 1800-luvun lopulla menettämässä otettaan. Kirkon asema heikkeni ja uskonto, jolla eri elämänalueet aikaisemmin oli nivottu yhteen, menetti yhteiskunnallista funktiotaan. Koulu-uudistuksen ja uusien opetussuunnitelmien myötä kristillinen kasvatus, jota vuoteen 1866 saakka oli toteutettu osana opetusta, jäi kasvattajien vastuulle. Uusien ei-uskonnollisten kasvatusideologioiden ilmaantuessa kristillisen kasvatuksen rinnalle yhteiskunnallisten rakenteiden muuttuessa alkoi näyttää siltä, että kasvatusajattelun vapautumisen myötä uskonnollinen kasvatus oli syrjäytymässä. Vuonna 1900 julkaistun kasvatusoppaan Lastemme kasvatus: kasvatusopillisia mietelmiä, suomentaja Ester Peltonen toteaa, että "se vanhan ja uuden kasvatustavan murrosaika, mikä meidänkin maassamme on tätä nykyä kaikkialla huomattavissa, vaatii luonnollisesti uusia kasvatusopillisia perusteita, joille se voi rakentua ja nojautua” (Ritter 1904, esipuhe). Yhteisöllisen kollektiivisuuden väistyessä individualismin tieltä, kollektiivinen kasvatusmetodi, johon kristillinen kasvatuskin tukeutui, näytti monien kasvattajien mielestä perin vanhanaikaiselta. Modernisoituvassa yhteiskunnassa haluttiin panostaa tulevaisuuteen eikä perinteeseen. Menneet sukupolvet, jotka aikaisemmin olivat olleet nuorten innovaationlähteinä, eivät voineet enää osoittaa suuntaa tuleville, koska heistä ei ollut enää esikuviksi.

Uskontotieteen eriytyminen itsenäiseksi tieteenalaksi ajoittuu myös 1800luvun loppuun, yhteiskunnallisen ja aatteellisen kulttuurikehityksen taitekohtaan. Yhteiskunnan henkisen ilmapiirin keveneminen ja tieteiden nopea kehitys mahdollisti 1800-luvun lopulla uskontotieteen oppiaineen syntymisen. Vuonna 1859 julkaistu Charles Darwinin teos On the Origin of Species by Means of Natural Selection, or the Preservation of Favoured Races in the Struggle for Life (suom. Lajien synty, 1980) toimi osaltaan kimmokkeena uskontotieteen kehittymiselle tarjotessaan mahdollisuuden tarkastella kristillistä, Raamatun auktoriteettiin perustuvaa maailmankuvaa ellei suorastaan kriittisesti niin ainakin tieteen kannalta. Uskontotiede omaksuikin verrattain nopeasti tieteellisen luonteen, mikä seikka ei kuitenkaan alussa näyttänyt edistävän tieteenalan hyväksymistä vaan pikemminkin päinvastoin: varsinkin maissa ja yliopistoissa, joissa teologian asema oli vahva, uskontotieteen katsottiin uhkaavan perinteisen teologian asemaa. Vähitellen asenne uskontotiedettä kohtaan kuitenkin muuttui, kun kiinnostus tieteitä ja tieteellistä maailmankuvaa kohtaan lisääntyi. Uskontotieteen oppituoleja alettiin perustaa eri yliopistoihin ja jo 1800luvun lopussa voidaan todeta uskontotieteen ansainneen paikkansa muiden tieteenalojen joukossa. Suomessa uskontotieteen kehittymistä edisti paitsi 1800-luvun lopulla yllättäen lisääntynyt kirkkokritiikki, joka kohdistui sekä kirkkoon että teologiaan, myös käytännön tilanne, kun Rafael Karsten vuonna 1907 nimitettiin vertailevan uskontotieteen dosentiksi. Uskontotiede oli näin virallisesti tunnustettu omaksi tieteenalaksi erotuksena esimerkiksi filosofiasta tai teologiasta. (Anttonen 1987, 31-39.) 


\section{TARJA KaKKO}

Uskontotiede tarjoaa tiedonväylän uskontoon osana yhteiskuntaa ja sen kulttuuria. Uskontotiede, erityisesti uskontososiologia, osoittaa, että uskonto on ennen kaikkea ryhmäilmiö. Sosiologit tarkastelevat uskontoa sosiaalisena järjestelmänä, kiinnittäen huomiota yhteiskuntarakenteisiin, instituutioihin ja symboliympäristöihin. Kulttuurin katsotaan muodostavan käsitejärjestelmiä, joiden avulla suunnistetaan (Suojanen 2000, 68-69). Käsitteet ja käsitejärjestelmät ovat kuitenkin alati muuttuvia, joten myös kulttuuriset muutokset ovat jatkuvasti käynnissä. Kulttuurien muuttuessa myös uskonnot kokevat muutoksia. Uskonto, jolla on aikaisemmin voinut olla yhteiskunnassa vakiintunut ja hallitseva asema, voi kulttuurimuutoksessa tulla syrjäytetyksi tai joutua ainakin luopumaan sille aikaisemmin kuuluneesta yhteiskunnallisesta statuksestaan.

Ranskalainen sosiologi Émile Durkheim oli 1800-luvun lopulla huolissaan siitä, mitä tapahtuu yhteiskunnalle, jos uskonnolla ei olekaan enää kansaa sitova ja lujittava funktio. Durkheimille uskonto oli ennen kaikkea pyhiä, toisin sanoen erityisiä ja kiellettyjä asioita koskevien uskomusten ja tapojen solidaarinen järjestelmä, joka yhdistää kaikki siihen uskovat yhdeksi moraaliseksi yhdyskunnaksi, jota kutsutaan kirkoksi. Durkheimin mukaan uskonto on sana, jonka merkityssisältö rakentuu tietylle väestölle yhteisistä ajatuksista ja yhteisistä toimintatavoista, jotka pitävät ymmärryksen aisoissa ja joita ihmiset eivät epäröi käyttää, koska ne on kehitetty yhdessä. Ponnekkuus, jolla jokainen yksilö on niitä mietiskellyt, kaikuu kaikkien mielessä. Yhteisön moraali on näin ollen yhteisesti muodostettu ja hyväksytty. Jopa teot, jotka rikkovat yhteisiä moraalisääntöjä, lujittavat yhteisöä. (Durkheim 1980, 61-64, 368-369.) Durkheim, jolle uskonto oli kollektiivinen representaatio, katsoi, että jumaluus on kollektiivinen voima, jonka alkulähteenä on yhteisö itse. Yksilöllä on tunne häntä hallitsevasta moraalisesta voimasta, joka on suurempi kuin ihminen itse ja jonka tulkkina ihminen toimii. Toisin sanoen yhteisön kollektiivinen voima palaa siihen yhteisöön, joka on sen muodostanut, ei kuitenkaan samanlaisena vaan määrältään paljon suurempana ja vahvempana. (Durkheim 1980, 374-375.)

Durkheim toteaa, että tiettyinä historian aikakausina ihmisten sosiaalinen vuorovaikutus tihenee ja aktivoituu. Näin tapahtuu muun muassa silloin, kun uskonnon yhteiskunnallinen funktio kasvaa. Kysymys on yksilöllisten voimien yleisestä vahvistumisesta, joilla on pitkään jatkuvat seuraukset. Yksilö aistii ympärillään samanlaisia tunteita, joita hän itse kokee ja hänestä tulee entistä luottavaisempi ja rohkeampi, hän tuntee jumalansa armon kohdistuvan itseensä. Kriisin yllättäessä, yhteisen uhan edessä, yhteisö kokoaa voimansa ja ryhtyy pohtimaan, mitä tilanteessa pitäisi tehdä. Ja "lääke" löytyy, sillä sitä etsitään yhdessä. Samalla yhteinen usko vahvistuu, Durkheimin mukaan "luonnollisella" tavalla ikään kuin uudesti syntyneen yhteisön keskuudessa. Usko vahvistuu, se syntyy uudelleen, koska olosuhteet ovat samat kuin silloin, kun se aikanaan syntyi. Ja kun usko on uudistettu, se voittaa kaikki ne epäilykset, joita se on ennen herättänyt ihmisten mielessä. Sillä on voimaa, jolla se pystyy vastustamaan kaikkia sisäisiä ja ulkoisia tekijöitä, jotka pyrkivät sitä heikentämään. (Durkheim 1980, 380-381.) 
1900-luvun vaihteen suomalaisessa kasvatuskeskustelussa uskonnon merkitys kollektiivisena voimana oli heikkenemässä. Suomalaisten muodostaman kollektiivin yhteiset ajatukset ja toimintatavat eivät saaneet enää kaikupohjaa luterilaisesta uskosta. Modernisaation myötä yksilön oma päätäntävalta alkoi kasvaa. Kasvatus, yhteiskunnan jäseneksi kasvattaminen ei saanut enää voimaansa pyhien asioiden muodostamasta solidaarisesta järjestelmästä, jonka evankelis-luterilainen kirkko muodosti kansalaisten mielissä, vaan joutui nyt koetteelle. Sekularisaatiosta huolimatta uskonnollisella kasvatuksella oli 1900 -luvun vaihteessa kuitenkin vielä merkittävä asema kasvatusvaihtoehtojen joukossa. Näin siksi, että kristillinen kasvatus oli erottamaton osa suomalaista yhteiskuntaa ja kulttuuria. Erno Lehtisen mukaan kasvatus on ennen kaikkea kulttuurin ja yhteiskunnallisten rakenteiden muovaamaa kulttuurista käytäntöä. Kasvatuksen yhtenä pyrkimyksenä voidaan nähdä lasten ja nuorten sosiaalistaminen yhteisön jäseneksi ja kulttuuristen käytäntöjen siirtäminen seuraaville sukupolville. (Lehtinen 2000, 12-13.) 1900-luvun vaihteen suomalaisessa yhteiskunnassa kristillinen kasvatus oli osa suomalaista kulttuuriperintöä, jolla oli jatkajansa. Luterilaisen kasvatusaatteen kannattajat halusivat osoittaa, että sekularisaatiosta huolimatta uskonnollisella kasvatuksella oli tulevaisuus. Luterilaisella kasvatusaatteella oli 1900-luvun vaihteessa "näytön paikka". Aatteen kannattajat eivät olleet vain teologisesti sivistyneitä kansalaisia vaan tavallisia suomalaisia vanhempia, jotka kristillisen kasvatuksen asteesta riippumatta olivat sisäistäneet kristillisen kasvatusperinteen eri piirteitä erottamattomaksi osaksi lasten kasvatusta ja oppineet luottamaan sen hyväksi havaittuihin käytäntöihin.

1800-luvun loppu oli Suomessa kansallisen heräämisen aikaa. Suomalaisen nationalismin alku ajoittuu 1860-lukuun, jolloin suomalainen kulttuuri syntyi. Suomen suuriruhtinaskunnalla oli 1800-luvun lopulla kiire tavoittaa se etumatka, jonka Länsi-Eurooppa oli suhteessa siihen saavuttanut. Kansalliset suurmiehet olivat kaikki yhtä mieltä siitä, että suomalaisten oli panostettava tulevaisuuteen ja näin ollen investoitava lapseen. J. V. Snellmanin historianfilosofian mukaan aatteet ja henki olivat maailmanhistorian eteenpäin vieviä voimia. Elämän merkitystä ja mielekkyyttä välitti kansalaisille luterilainen kristillisyys. Arvot ja ihanteet oli annettava kansalle ylhäältä ikään kuin Jumalan käskyinä. Kasvatuksesta tuli käsite, joka liitettiin paitsi kansalaisten sivistystason kohottamiseen myös suomalaisen yhteiskunnan rakentumiseen.

On vaikea arvioida, mikä on historian eteenpäin vievä voima: talous, politiikka vai aatteet. Historiallista kehitystä tarkasteltaessa on kuitenkin todettava Heikki Kirkisen tapaan, että "nykyihminen on pitkän historiallisen kehityksen tulos". Nykyihmisen tiedollinen ymmärtäminen edellyttää ihmiskunnan historian entistä syvempää tarkastelua, käyttäen apuna historian lähteitä. Paikallisesti se tarkoittaa yhteiskunnan ja sen kulttuurin tarkastelua ikään kuin sisältä käsin, kehitystä seuraten ja ymmärtäen, sillä menneisyyteen sisältyy ihmiskunnan elämänkokemus. Menneisyydessä on tieto, jota voimme soveltaa tulevaisuutta varten. (Kirkinen 1987, 16.) 


\section{TARJA KAKKO}

\section{KirjallisuUs}

ANTTONEN, VEIKKO 1987: Uuno Harva ja suomalainen uskontotiede. Suomi 138. Helsinki: Suomalaisen Kirjallisuuden Seura.

DURKHEIM, ÉMILE 1980: Uskontoelämän alkeismuodot. Helsinki: Tammi. [1912] KIRKINEN, HEIKKI 1987: Historian rakenteet ja voimat. Johdatus historian filosofiaan. Helsinki: Kirjayhtymä.

LEHTINEN, ERNO 2000: Uskomus, tieto, tiede. - Rinne, Risto \& Kivirauma, Joel \& Lehtinen, Erno (toim.), Johdatus kasvatustieteisiin. Helsinki: WSOY.

RITTER, P. H. 1900: Lastemme kasvatus: kasvatusopillisia mietelmiä.

Porvoo: WSOY.

SUOJANEN, PÄIVIKKI 2000: Uskontotieteen portailla. Historiaa ja tutkimussuuntia. Helsinki: Suomalaisen Kirjallisuuden Seura.

Kakko, Tarja 2005: Kurissa ja Herran nubteessa. Luterilainen kasvatusaate 1900-luwun vaibteen Suomessa. Sarja C, osa 236. Turku: Turun yliopisto.

FT Tarja Kakko on turkulainen uskontotieteilijä. 